\title{
Educational Status of Women in Jammu and Kashmir with Special Reference to Rural Areas
}

\author{
Showkat Ahmad Bhat ${ }^{1 *}$, Aashaq Hussain Bhat ${ }^{2}$, Dr. P. Chinnathurai ${ }^{3}$
}

\section{ABSTRACT}

In India, though much emphasis is being laid on the gender equality in terms of education, yet discrimination in access to education does exist. There is a rural and urban divide in access to education for women. In Jammu and Kashmir too, female literacy rate is quite low and stands at 58.01 percent. The rural female literacy rate in $\mathrm{J} \& \mathrm{~K}$ is 53.36 percent to 70.19 percent for urban females which earlier in the Census of 2001 was 36.7\% at rural and $61.9 \%$ at the urban level, respectively. Also, there is a large gap in the male and female literacy levels in this border state. The present study examines the issues of education for empowering women in the rural areas of Jammu and Kashmir and seeks to address the challenges towards education of rural women in Jammu and Kashmir.

Keywords: Women Education, Female Literacy Rate, Women Empowerment.

Education plays an important role in socio-economic development of a country; moreover women education has immense importance in this regard. Educated women are not only raising their own socio-economic status but they are enhancing intellectual horizon of their children, uplifting socio-economic condition of their family and playing a significant role in raising their family status. There is a strong linkage between education of women and the development of a nation. In fact, women education has come to be considered more important than that of men. Dr. Karve, a pioneer for the cause of women education, once said, "If you educate a man, you educate an individual, if you educate a woman, you educate the whole family.” The University Education Commission (1949) has also rightly remarked: "There cannot be an educated man without an educated woman. If general education is to be limited to men or to women, that opportunity should be given to women, for then it would more surely be passed on to the next generations.” On the other hand, education also makes the women strong, empowered, creates

\footnotetext{
${ }^{1}$ Ph.D Research Scholar, Department of Political science and public administration, Annamalai University, India

${ }^{2}$ Ph.D Research Scholar, Department of Political science and public administration, Annamalai University, India

${ }^{3}$ Associate Professor, Department of Political Science and Public Administration, Annamalai University, India

*Responding Author

(C) 2016, S Bhat, A Bhat, P Chinnathurai; licensee IJIP. This is an Open Access Research distributed under the terms of the Creative Commons Attribution License (http://creativecommons.org/licenses/by/2.0), which permits unrestricted use, distribution, and reproduction in any Medium, provided the original work is properly cited.
} 
self- reliance and brings determination in life. It has a central role in the struggle to achieve women's equality and empowerment both in the family as well as in the community. Lack of education, information and low level of literacy aggravate the situation of deprivation in all sector of life.

Education helps in generating awareness among women about their legal, social, political and economic rights, provisions and privileges to fight against all sorts of social discrimination. It enables them to realize their potentialities, developing skills, seeking employment and improving their nutritional and health conditions. Education helps women in lightening the burden of tradition of ignorance and strict seclusion within the home, in equipping them with the expertise and knowledge required to play modern roles, in widening their horizons and in raising their general status in society. Therefore, educating women encourages not only their political participation and economic independence but also improves their quality of life and through them of the whole family and then whole nation in broader sense..

\section{Objectives}

1. To trace the government schemes for empowering women education in rural areas of Jammu and Kashmir.

2. To find out the challenges for empowering women education in rural areas of Jammu and Kashmir.

\section{METHODOLOGY}

The study is mainly based on secondary data. The main sources of data are the Census reports, Websites, Research articles and Books.

\section{Educational Policies for Rural Women In Jammu And Kashmir}

According to Census 2011, the literacy rate in Jammu and Kashmir is 78.26 percent for males and 58.01 percent for females. The female literacy rate is less than the male literacy rate. The literacy rate for rural females is 53.36 percent and 70.19 percent for urban females. Earlier in Census 2001, it was $36.7 \%$ and $61.9 \%$ at rural and urban level, respectively thus there is a large gap in the male and female literacy rates.

Over the years, government has announced several schemes to promote education among women which include Sarva Shiksha Abhiyan (SSA), National Programme for Education of Girls at Elementary Level (NPEGEL) and Kasturba Gandhi Balika Vidyalaya (KGBV) etc. With the help of these target oriented interventions, the number of educational institutions has increased over the years, resulting into maximum area coverage besides decreasing the average distance per school. The improvement in the statistics reflect the seriousness of the Jammu \& Kashmir Government towards the development of women in state, however, the fact remains that despite the progress made, the female literacy has remained very low in the state as compared to men. 


\section{Educational Status of Women in Jammu and Kashmir with Special Reference to Rural Areas}

Various factors like peculiar topography of Jammu and Kashmir state, the sparse network of schools in rural areas, the majority of population living in far flung and inaccessible areas, lack of easy access to institutions, lack of infrastructure, weather vagaries, conflict situations etc. create hindrance in achieving the desired goal of universalization of literacy in the violence-hit state.

Though both the centre and the state governments are committed to provide education to the children in Jammu and Kashmir, there are still many challenges before the universalization of education in the state which is faced with a conflict since past 24 years. The female literacy rate in J\&K, as per Census 2011, is $58 \%$. Among the other Indian state and Union Territories, Jammu and Kashmir has one of the lowest female literacy rates at $58 \%$ besides Rajasthan (52.7\%), Bihar (53.3\%), Jharkhand (56.2\%), Uttar Pradesh (59.3\%), Arunachal Pradesh (59.6\%) and Andhra Pradesh (59.7\%). There is a large gap in the male and female literacy rates. The literacy rate of district Ramban is the lowest with $56.90 \%$, the male literacy rate being $71.97 \%$ and female literacy rate $40.04 \%$ only. Jammu district has the highest literacy rate of $83.98 \%$ with 89.77\% males and $77.41 \%$ females are literate. The lowest female literacy rate is $40.04 \%$ in District Ramban and the highest female literacy rate of $77.41 \%$ in Jammu district. There are 7 districts where female literacy rate is even below $50 \%$. There is a huge gap in male female literacy ratios also.

To increase enrolment and decrease female dropouts, a large number of programmes have been implemented in Jammu and Kashmir including Sarva Shiksha Abhiyan (SSA), a flagship programme aimed at achieving the objectives of Universalisation of Elementary Education, retention and bridging all gender and social gaps, strives to secure the right to quality basic education for all children in 6-14 years age group. This scheme is being implemented in the State of Jammu and Kashmir for improvement in Gross Enrolment ratio apart from UEE and Universal retention like rest of the country. Girls Education is one of the important components of Sarva Shiksha Abhiyan. Sarva Shiksha Abhiyan recognizes that ensuring girl's education requires changes not only in the education system but also in societal norms and attitudes. A two-pronged gender strategy has therefore been adopted, to make the education system responsive to the needs of the girls through targeted interventions which serve as a pull factor to enhance access and retention of girls in schools and on the other hand, to generate a community demand for girls' education through training and mobilization.

Education of girls, especially those belonging to the scheduled castes and scheduled tribes, OBC and minority is the primary focus in Sarva Shiksha Abhiyan. Efforts are being made to mainstream gender concerns in all the activities under the Sarva Shiksha Abhiyan programme. Mobilization at the habitation/village/urban slum level, recruitment of teachers, up gradation of Primary into upper primary schools, incentives like midday meals, scholarships, educational provision like textbooks and stationery, all takes into account the gender focus. 


\section{CHALLENGES TO RURAL WOMEN EDUCATION IN JAMMU AND KASHMIR}

Despite the efforts being made for rural education of girls and women in Jammu and Kashmir, there are still many challenges in the area. The gender gap in $\mathrm{J} \& \mathrm{~K}$ is also higher than the national average.

Jammu and Kashmir is a Muslim dominated state which is a conservative and religious society also. Though urban areas have witnessed a lot of change in terms of education of girls and women in the past few years, in rural areas the parents still prefer girls to stay at home till they go to their 'own homes' after their marriage. The conflict in Jammu and Kashmir has resulted in a breakdown of the society. Many rural families are without any earning member. The girls have become orphans and there is no source of sustenance in their families. This has also prevented them from seeking education. As the economy of rural Jammu and Kashmir has met with severe set-back during past years, parents are not in a position to educate their girl children. If they have to make a choice between educating a male child and a female, they prefer the former. Poverty, undoubtedly, is one of the main reasons of the inability for the girl child in rural areas to obtain basic education. Hundreds of girls in rural areas are not able to attend schools because their families are not able to provide money for the education.

Though situation is improving in Jammu and Kashmir, yet the prolonged violence in J\&K since past 24 years have prevented the girls from going to schools and colleges, as their parents are worried about the physical security of the girls. There are issues like lack of accountability/ Teacher absenteeism, paucity of Women Teachers and deterioration in the quality of instructors and instruction which are still creating hurdles in education of girls in rural areas.

Accountability factor in the schools has gone down in these past years in Jammu and Kashmir. Teachers do not go to their places of postings as they do not want to serve in rural areas. Even those teachers who hail from rural areas like Kupwara, Baramulla etc want to be posted in urban areas or at least in district headquarters. Majority of schools particularly in the rural areas are suffering because of lack of supervision. Attendance of teachers in these schools is always very thin and many schools having single teachers remain closed for days together. In rural and remote areas attending schools is the last priority of most of the teachers and it has in fact become a subsidiary occupation for them while as their primary occupations are fruit, walnut and other business.

Jammu and Kashmir has hilly mountainous terrain mostly close to border areas. The variations in literacy rates from district to district are very large because of some social taboos, geographical location and poverty. The large gaps in the literacy rates from district to district and from rural and urban areas are mainly due to variegated geographical features of the state. The mountainous regions have lower literacy rates because these areas are victims of double marginality. Gender based inequalities are prominent. Issues like social discrimination and economic exploitation, 
occupation of girl child in domestic chores, girls working in the households and taking care of the younger siblings or needed to earn money for their families by working in the agricultural field are quite visible.

The state has inadequate schooling infrastructure. 33.68\% of primary schools are without their own buildings and are being run in private accommodations which are not generally conducive for good teaching atmosphere. $25.74 \%$ of upper primary schools have inadequate accommodation as per DISE data 2010-11. In fact, most of the schools upgraded to the upper primary have only three rooms against the requirement of at least 6 rooms. Teachers' absenteeism in rural areas, the costs of transportation, materials and uniforms are among other impediments to rural women education. Thus, the significance of education for girls and women is shaped by the existing gender division in society. Rural Kashmir also echoes the popular sentiment is that an educated daughter can be a liability to her family.

\section{CONCLUSIONS AND SUGGESTIONS}

Of the total population of Jammu and Kashmir State, around 72.79 percent live in the villages of rural areas. In actual numbers, total population of rural areas of Jammu And Kashmir State is $9,134,820$. In rural areas of Jammu and Kashmir, literacy rate for males and female stood at $75.51 \%$ and $53.36 \%$.

Keeping in view the fact that a significant number of population resides in rural areas of Jammu and Kashmir, these people should have the same quality of life as is enjoyed by people living in sub urban and urban areas. However, this is not the reality. An overabundance of government initiatives to provide access to primary education may be underway, but issues of equity, quality, and access remain areas of concern in rural schools. Children in rural areas continue to be deprived of worth education owing to factors like lack of competent and committed teachers, lack of textbooks or teaching-learning materials, and so on. Present Scenario of rural education in Jammu and Kashmir is quite poor. Persistent female illiteracy is a major impediment to women's empowerment; empowering women and adolescent girls through literacy and education can enable them to develop analytical skills on gender, development and other issues.

Rural women of Jammu and Kashmir should be empowered through education as they form an important part of the society worldwide. Education would help them to be aware of new productive opportunities in the areas of entrepreneurship skills acquisition, greater income generation and better opportunities in the world of employment greater income opportunities to better their lot in the worldwide communities. Rural women should be encouraged to enroll in literacy programmes. They should be encouraged to know that the benefits that would accrue to their being literate is greater than the economic benefits they are currently enjoying and so they should take bold steps to leave their trades at the stipulated time for literacy classes. Awareness programmes should be floated on posters, and media houses and children in schools should be 
made to encourage their mothers on literacy education. The government at all levels should fund literacy programmes, make it interesting to women so as to entice them to enroll for literacy classes.

\section{Acknowledgments}

The author appreciates all those who participated in the study and helped to facilitate the research process.

\section{Conflict of Interests}

The author declared no conflict of interests.

\section{REFERENCES}

Annual Status of Education Report-Rural, (2011). Survey Results. ASER Center, Pratham.

Chothani, S.K. (2013). Rural Education in India. Indian Journal of Applied Research, 3(3).

Dabla, N., \& Islam, K. (1995). Gender discrimination in the Kashmir Valley. New Delhi: Gyan Publishing House.

Directorate of Economics and Statistics (2011-2012). Economic Survey. Jammu and Kashmir Government.

Gupta, N.L. (2003). Women's Education Through Ages. New Delhi: Concept Publications Co.

Kavita, S. (2006). Impact of Violence on Girls Education in Kashmir Valley. New Delhi: Wiscomp Monograph Series.

Kavita, S. (2011), Voices Unheard-Women, Conflict and Kashmir. Gurgaon: Shubhi Publications.

Khaliq, S. (2012). Women in rural Kashmir are forced to quit education early. Asian News International (ANI).

Madhosh, A.G. (2004). Study on Women and Children under Armed Conflict in Kashmir. National Institute of Public Cooperation and Child Development.

Ministry of Home Affairs (2011). Census of India 2001 and 2011. Government of ndia.

Nayar, U. (1993). Universal Primary Education of Rural Girls in India. New Delhi: National Council of Educational Research and Training.

Olufunke, A.M (2011). Literacy: A Potent Tool for Women Empowerment. International Review of Social Sciences and Humanities, 1(2).

Ramachandran, V. (2009). Towards Gender Equality in Education. New Delhi: National University of Educational Planning and Administration.

Rao, R.K. (2001). Women and Education. Delhi: Kalpaz Publications.

Sudha, T. (2010). Employment and Empowerment of Rural Women in India. New Delhi: Global Research Publication.

How to cite this article: S Bhat, A Bhat, P Chinnathurai (2016), Educational Status of Women in Jammu and Kashmir with Special Reference to Rural Areas, International Journal of Indian Psychology, Volume 3, Issue 4, No. 65, ISSN 2348-5396 (e), ISSN: 2349-3429 (p), DIP:18.01.150/20160304, ISBN: 978-1-365-34680-4

(c) The International Journal of Indian Psychology, ISSN 2348-5396 (e)| ISSN: 2349-3429 (p) | 182 